Ryabushka L.B.

Ph.D, Associate Professor

Bondarkova D. $V$.

Ukrainian Academy of Banking of The National Bank

of Ukraine

\title{
THE INFLUENCE OF THE SHADOW ECONOMY ON BUDGET REVENUES
}

Abstract There are modern problems concerning influence of the shadow economy on the formation revenues of the General budget, systematization structuring components, which form the shadow economy, reasonable factors of influence of the shadow economy on revenues; systematization methods of determination of the shadow economy in the context of national and international experience, methodological approach to assess the impact of the level of shadow economy on revenues of the General budget, the forecast of lost revenues of the General budget on the basis of extrapolation in the work.

Keywords: shadow economy, revenues, methods, factors of influence, lost government revenues, forecast of revenues.

\section{Introduction}

The development of the economy is influenced by extemal and internal factors. One of them is the impact of the shadow economy on the formation of revenue. It proves relevance of the research topic, which is particularly important in the context of overcoming the crisis and to stabilize the budget system. The Problems of analysis of the shadow economy in general and its impact on the formation of the General budget are researched by such scientists as F. Schneider [1] M. Friedman [2] J. Thomas [3] S. Varnaliy [4] V. Yurynets [5] V. Dadalko [6] N. Skvortsov [7] V. Popovici [8] and others.

\section{Problem}

Development of methodological principles, creation of practical recommendations to assess the impact of the level of shadow economy on revenues of the General budget.

\section{Results}

Analysis and systematization of scientific views on the interpretation of the term «shadow economy» has allowed to formulate the author statement which, in our opin- 
ion, is the most exhaustive. The shadow economy is an economic activity of businesses and individuals that direct to generate revenues and meet human needs. It is characterized by uncontrollable processes of production, distribution, exchange and consumption and doesn't take into account in official statistics. Such structuring components as forms (criminal, not:legal, illegal, informal, not official), types (internal and external, intentional and unintentional, individual and collective), shapes (second, gray, black), groups (one-time, seasonal, permanent) belong to the structural elements of the shadow economy (fig. 1).

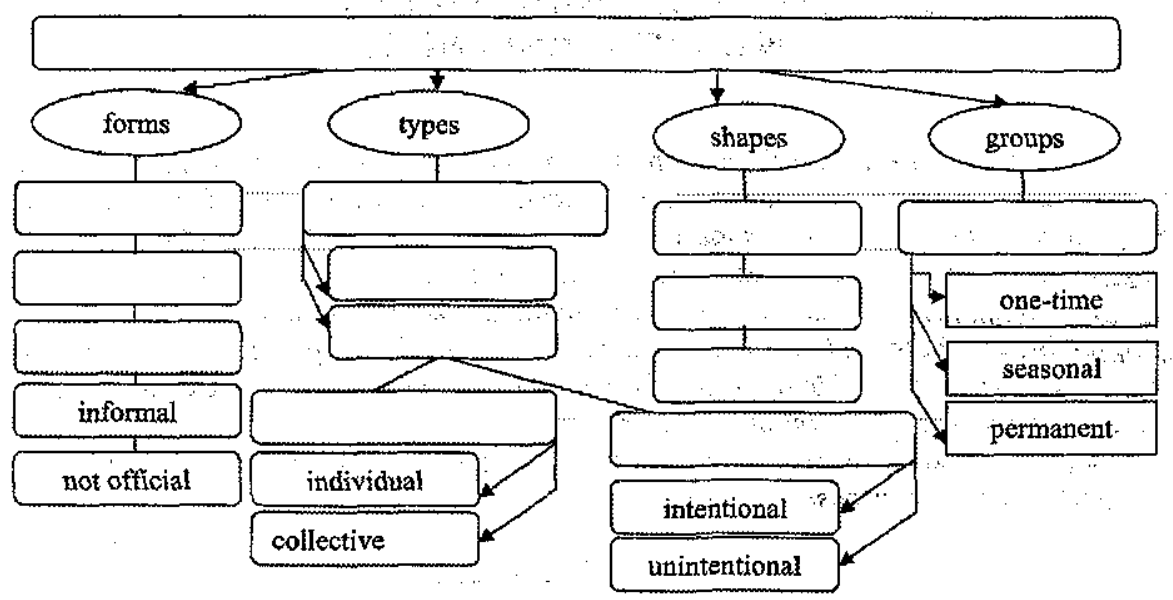

Fig. 1 - Systematization of structuring components of the shadow economy

This is systematization of the definition of the shadow economy in the context of national and international experience. Scientists distinguish such methods: structural, integral, special methods and methods of specific indicators (direct, indirect), the method of soft modeling, the method of sustainable relationships, the method of hidden variables and an approach, which is based on the differences between statistics indicators of GDP in context of revernes and costs. The level of the shadow economy is calculated on the basis of several methods: financial, monetary method, «Expenditures of Individuals - retail trade», electric method in Ukraine.

The factors of influence of the shadow economy on government revenues are grounded in the investigation: economic (financial crisis, the high level of taxation), social (low standard of living, high unemployment), legal (low level of equipment of law enforcement agencies, the low level of legal culture, weak training of workers of law enforcement institutions), institutional (corrupt public services of various government structures, the use of state property organizational structures for receiving informal private income by government officials and managers). And there are fac- 
tors that influence on the shadow economy: subjective (falling-off of production or crisis in defining sectors of economics, shortcomings in the current models of competition), objective (existence of socially active group of people who violate the legislation in order to obtain certain economic benefits) (fig. 2).

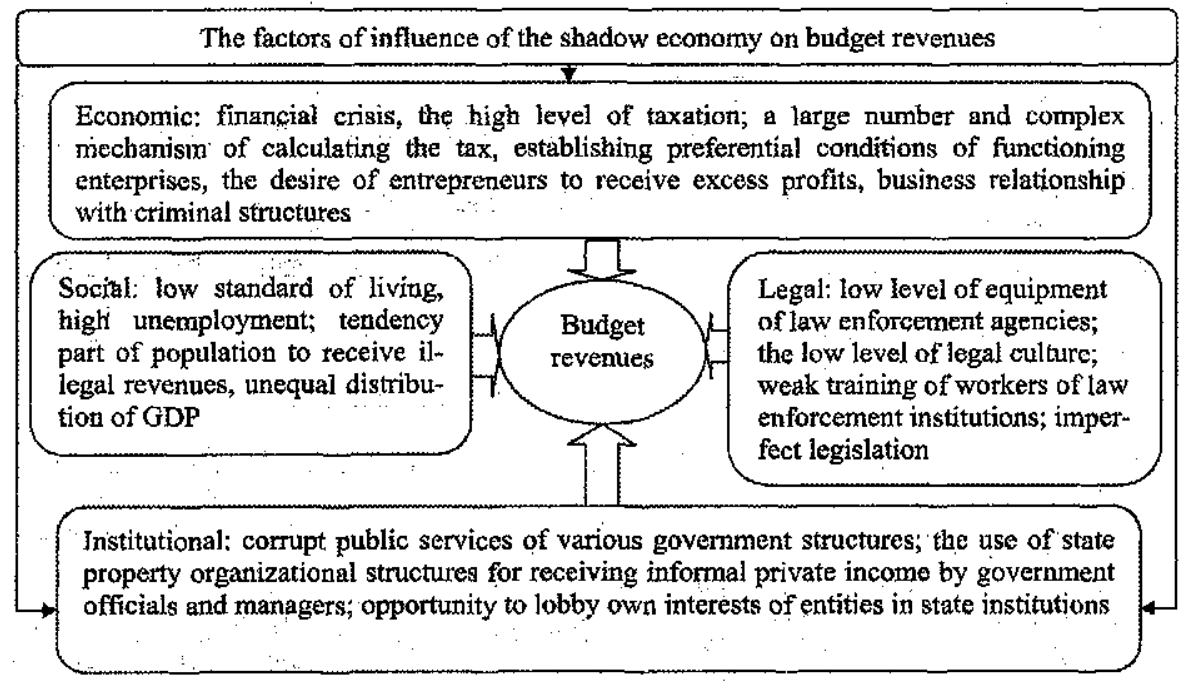

Fig. 2 - The factors of influence of the shadow economy on budget revenues [9-11]

There is estimation the impact of the level of shadow economy on the formation of general budget in Ukraine in the context of the study. The data for further analysis is presented in Table 1.

There is information on the amount revenues of General budget, tax and non tax revellues, tax on income, value added type tax, corporate income tax in percent of GDP in order to bring data in comparative form in the work. 
Table 1 - Dynamies of the Consolidated Budget, GDP, level of shadow economy in 2003-2011 [12-15]

\begin{tabular}{|c|c|c|c|c|c|c|c|c|c|}
\hline \multirow[t]{2}{*}{ Indicator } & \multicolumn{9}{|l|}{ Years } \\
\hline & 2003 & 2004 & 2005 & 2006 & 2007 & 2008 & 2009 & 2010 & 2011 \\
\hline $\begin{array}{l}\text { Government } \\
\text { revenues of the } \\
\text { General Budget, } \\
\text { billion hr. } \\
\text { including }\end{array}$ & 75,3 & 92,5 & 134,2 & 171,8 & 219,9 & 297,9 & 288,6 & 314,4 & 398,3 \\
\hline $\begin{array}{l}\text { tax revenues, billion } \\
\text { hr. }\end{array}$ & 54,4 & 65,1 & 98,2 & 125,1 & 161,2 & 227,2 & 208,1 & 234,5 & 334,6 \\
\hline $\begin{array}{l}\text { corporate income } \\
\text { tax, billion hr. }\end{array}$ & 13,3 & 16,2 & 23,5 & 26,1 & 34,3 & 48 & 33,2 & 40,2 & 55 \\
\hline $\begin{array}{l}\text { value added type } \\
\text { tax, billion } \mathrm{hr} \text {. }\end{array}$ & 12,7 & 16,7 & 34 & 50,3 & 59,4 & 92,1 & 84,6 & 86,5 & 130,2 \\
\hline $\begin{array}{l}\text { tax on income, } \\
\text { billion hr. }\end{array}$ & 13,5 & 13,2 & 17,3 & 22,9 & 34,7 & 45,9 & 44,4 & 50,9 & 60,1 \\
\hline $\begin{array}{l}\text { non tax revenues, } \\
\text { billion hr. }\end{array}$ & 18,2 & 23,6 & 31,8 & 41,2 & 48,6 & 60,5 & 73,8 & 73,6 & 59,7 \\
\hline $\begin{array}{l}\text { capital tax, billion } \\
\text { hr. }\end{array}$ & 1,8 & 2,5 & 2,8 & 3,3 & 6,4 & 6,9 & 3,8 & 3,2 & 2,4 \\
\hline $\begin{array}{l}\text { social contribution, } \\
\text { billion hr. }\end{array}$ & $\sim$ & $=$ & 1,3 & 2,2 & 3,7 & 3,3 & 2,3 & 2,8 & 1,2 \\
\hline $\begin{array}{l}\text { other revenues, } \\
\text { billion hr. }\end{array}$ & 0,9 & 1,3 & 0,1 & 0 & 0 & 0 & 0,6 & 0,3 & 0,4 \\
\hline GDP, billion hr. & 267,3 & 345,1 & 441,5 & 5442 & 720,7 & 948,1 & 913,3 & 1082,6 & 13166 \\
\hline $\begin{array}{l}\text { Level of shadow } \\
\text { economy, } \% \text { GDP }\end{array}$ & 39 & 28 & 29 & 30 & 28 & 34 & 39 & 38 & 34 \\
\hline
\end{tabular}

It is possible to assess the impact of the level of shadow economy on budget revenues through the use of economic-mathematical methods of correlation and re gression analysis. The dynamics of general budget and the level of shadow economy are presented in Fig. 3. Overall, there was the gradual growth of government revenues of the General Budget from 92.5 billion to 398.3 billion and the Level of shadow economy - from $28 \%$ to $34 \%$ of GDP for the period 2004-2011 [12-15]. The sharp increase of the level of shadow economy led to a decrease of tax revenues, capital taxes, social contribution and other revenues in 2009-2010. This tendency is showed the deviation of enterprises from paying tax to the General Budget. The results of the analysis showed that a gradual increase of the level of shadow economy led to a gradual increase of government revenue of the General Budget in general and in the context of its components. 


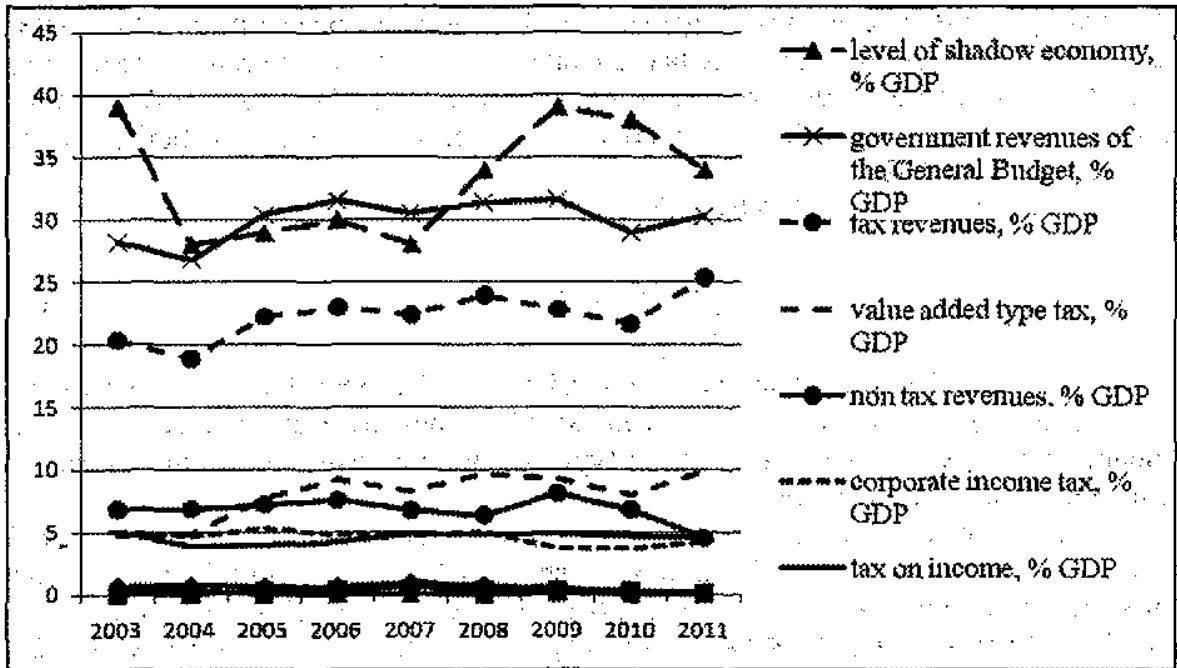

Fig. 3 - The dynamics of the shadow economy and the components of General budget, \% of GDP (calculated according to the [12-15])

But with a significant growth of the shadow economy they observed a sharp decrease of shadow economy of the General Budget. The increase of the shadow economy led to a decrease of revenues by reducing non tax revenues, corporate income tax, tax on income, capital tax and social contribution. As a result it is necessary to calculate the amount of lost government revenues of the General Budget taking into account the level of shadow economy by the following formula:

$$
\mathbf{T}_{i_{i}}=\sum_{t=1}^{n}\left(\mathrm{~T}_{i_{t}} \times \mathrm{I}_{\mathrm{t}} \times \varphi_{i_{q}}\right)
$$

where $T_{\mathbf{l}}-$ lost government revenues of the General Budget; $\mathbf{T}_{i_{t}}-$ real goverment revenue of the General Budget in context of its components (tax revenue, corporate income tax, tax on income, value added type tax, capital tax and social contribution); $\mathbf{I}_{t}$ - the level of shadow economy in the $t$-th year; $\varphi_{i_{t}}$-coefficient of the influence of the level of shadow economy on goverment revenue of the General Budget in the context of the components (coefficient of the influence of the level of shadow economy on revenues evaluated on the basis of correlation and regression analysis).

The influence of the level of shadow economy on tax revenues is 0.11 , on the value added type tax is 0.05 , on corporate income tax is 0.57 , on tax on income is 0.71 , on tax revenues is 0.57 , on capital tax is 0.54 , on social contribution is 0.58 . 
According to the calculations in general the lost government revenue of the State Budget is 151.84 billion, including tax revenue -56.31 billion. (corporate income tax -55.41 billion, value added type tax -9.63 billion., tax on income -73.32 billion), non tax revenues -83.51 billion, capital tax -5.86 billion., social contribution -6.16 for the period 2003-2011's.

Calculated revenues $\left(T_{r_{1}}\right)$ have the following form:

$$
\mathbf{T}_{\mathbf{r}_{\mathrm{i}}}=\sum_{\mathrm{t}=1}^{n}\left(\mathrm{~T}_{\mathrm{i}_{t}}+\mathrm{T}_{\mathbf{i}_{\mathrm{i}}}\right)
$$

We shows the actual and calculated indicators of general budget (according to the formula 2) in general and in the context of components (tax revenue, corporate income tax, tax on income, value added type tax, non tax revenues, capital taxes, social contribution) in the work.

There is calculation the share of lost revenues of General budget in adjusted revenues. According to the calculations the shate of lost revenues of General budget in adjusted revenues is $6,67 \%$ in $2003,6,15 \%-2004,9,05 \%-2005,12,09 \%-$ $2006,14,42 \%-2007,22,14 \%-2008,26,65 \%-2009,29,82-2010,24,76 \%$ 2011 year. It should be noted that the value of this indicator increased from $6.76 \%$ to $24.76 \%$ during the period, which is a bad thing and shows increasing the shortage in the revenues of General budget. There is decreasing lost revenues of General budget in calculated revenues from 29.82 to $24.76 \%$ in 2011 compared to 2010 . The largest part of the lost revenues of general budget in adjusted revenues were in $2010(29,82$ $\%)$, the lowest - in $2004(6,15 \%)$.

There is a forecast of lost government revenue of the General Budget based on the basis extrapolation for 2012-2014 years (Fig. 4). They forecast the growth of lost tax revenue $(26,13 \%$ GDP), corporate income tax $(25,03 \%$ GDP), tax on income $(34,15 \%$ GDP), value added type tax (4,54\% GDP), non tax revenue ( $37,75 \%$ GDP), capital tax (2,45\% GDP), and social contribution (2,99\% GDP) before 2014 year. $Д$

The results of the forecasting emphasize expert evaluation of deterioration of financial stability, sequestration of real government revenues of the General Budget for the next three years due to the recession of the econormy of Ukraine and to the increasing of the level of shadowing. The necessity of strengthening measures against the shadow economy is proved in the following directions in Ukraine: strengthening the financial security and monitoring money laundering, development and implementation of the annual programs of struggle with shadow economy, combating with violations, increasing the transparency of government, improving the legislation with the purpose of decreasing of the level of shadow economy. 


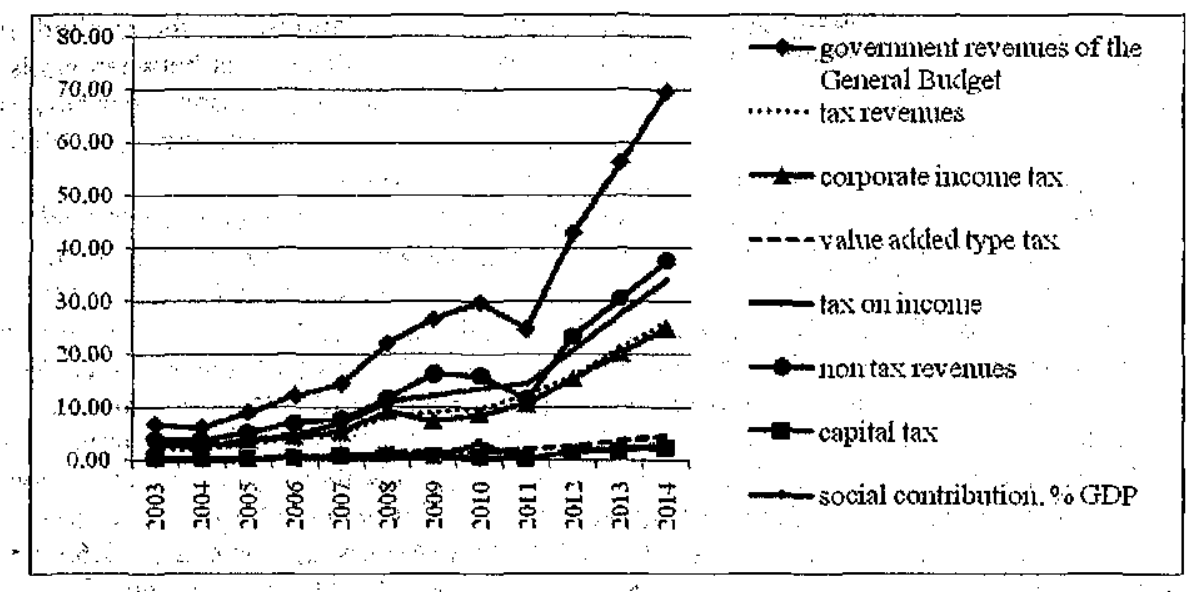

Figure. 4 - Prediction of lost goverment revenues of the General budget for the period $2012-2014, \%$ of GDP

\section{Conclusions}

There are certain results of our investigation. There is proposition author definition: "shadow economy" is an economic activity of businesses and individuals that direct to generate revenues and meet human needs; it is characterized by uncontrollable processes of production, distribution, exchange and consumption and doesn't take into account the official statistics. There are analyzation and systematization structuring components such as forms (criminal, not legal, illegal, informal, not official), types (internal and external, intentional and unintentional, individual and collective), shapes (second, gray, black), groups (one-time, seasonal, permanent) belong to the structural elements of the shadow economy. The factors of influence of the shadow economy on government revenues are grounded in the investigation: economic (financial crisis, the high level of taxation), social (low standard of living, high unemployment), legal (low level of equipment of law enforcement agencies, the low level of legal culture, weak training of workers of law enforcement institutions), institutional (corrupt public services of various government structures, the use of state property organizational structures for receiving informal private income by government officials and managers) and factors that influence on the shadow economy: subjective (falling off of production or crisis in defining sectors of economics, shortcomings in the current models of competition), objective (existence of socially active group of people who violate the legislation in order to obtain certain economic benefits). There is systematization of the definition of the shadow economy in the context of national and international experience. Scientists distinguish such methods: structural, integral, special methods and methods of specific indicators (direct, indirect), 
the method of soft modeling, the method of sustainable relationships, the method of hidden variables and an approach, which is based on the differences between statistics estimates of GDP by revenues and costs. The level of the shadow economy is calculated on the basis of several methods: financial, monetary method, «Expenditures of Individuals - retail traden, electric method in Ukraine.

There is proposition methodical approach to assess the impact of the level of shadow economy on budget revenues (tax revenue, corporate income tax, tax on income, value added type tax, non tax revenues, capital taxes, social contribution) through the use of economic-mathematical methods of correlation and regression analysis. There is identification of coefficients of the influence of the level of shadow economy on tax revenues (0.11), on the value added type tax $(0.05)$, on corporate income tax $(0.57)$, on tax on income $(0.71)$, on tax revenues $(0.57)$, on capital tax $(0.54)$, on social contribution (0.58). According to the calculations in general the lost government revenue of the General Budget is 151.84 billion, including tax revenue 56.31 billion. (corporate income tax -55.41 billion, value added type tax -9.63 billion., tax on income -73.32 billion), non tax revenues -83.51 billion, capital tax 5.86 billion., social contribution -6.16 for the period 2003-2011's. We calculated adjusted indicators of General budget in general and in the context of components (tax revenue, corporate income tax, tax on income, value added type tax, non tax revenues, capital taxes, social contribution) in the work.

There is a forecast of lost government revenue of the General Budget based on the basis extrapolation for 2012-2014 years. The results of the forecasting emphasize expert evaluation of deterioration of financial stability, sequestration of real government revenues of the General Budget for the next three years due to the recession of the economy of Ukraine and to the increasing of the level of shadowing. The necessity of strengthening measures against the shadow economy is proved in the following directions in Ukraine: strengthening the financial security and monitoring money laundering, development and implementation of the annual programs of struggle with shadow economy, combating with violations, increasing the transparency of government, improving the legislation with the purpose of decreasing of the level of shadow economy.

\section{Literature}

1. Schneider F. Measuring the size and development of the shadow economy. Can the causes be found and the obstacles be overcome? /F. Schneider // Brand-staetter H., Guth W.: Essays on Economic Psychology. - Berlin: Springer Publishing Company. - 1994:- P. 193-212.

2. Friedman M. The Drug War as a Socialist Enterprise / Milton Friedman // Friedman and Szasz on Liberty and Drugs / Edited by A. S. Trebach, K: B. Zeese. Washington: The Drug Policy Foundation. - 1992 - - P. 223-236.

3. Thomas J. Quantifying the black economy: «measurement without theory" yet again? / J. Thomas // The Economic journal, - 1999. - p. 387. 
4. Vamaliy Z. S. Economic Security / Z. S. Varnaliy. - K.: Knowledge, 2009. - 647 p. - ISBN: 978-966-346-761-0.5.

5. Yurynets V. Peculiarities of shadow economy in Ukraine / V. Yurynets, S. Londar $/ /$ «Econonic Journab». - 1999. - № 11-12.

6. Dadalko V. A. Shadow economy and power crisis: challenges and solutions / V. A. Dadalko, E. E. Rumyantsev, D. A. Peshko. - Minsk, 2000:-416 p. - ISBN 966-608-355-8.

7. Popovic V. Shadow economy as a object of economic Criminology/ V. M. Popovych. - K.: Legal sources. - 1998. - 448 p. - ISBN 966-657-633-4.

8. The financial security of the state under the influence of capital market development: dissertation of candidate economy sciences: specials 08.00.08 - Money, Finance and Credit / T. G. Cubach. - Sumy [B. W. ] 2012. $-21 \mathrm{p}$.

9. Pryvarnykov I.Y. Shadow economy in Ukraine: causes, scope and ways to reduce / I. Y. Pryvarnykova. / / State and Regions. Ser. «Economics and Entrepreneurship»). 2010. - № 2.-C. 163-167.

10. Drozdov A. Sources the formation of the shadow economy in Ukraine / Drozdov / / Academic record of Taurian National University. - Issue. 12 (51). - No 1 .

11. Survey on the topic: The shadow economy in Ukraine: IAA «Marketing and Consulting" Research Center of Corporate Relations. www.jamik.ru,

12. Budget Monitoring: Institute for Budget and Social and Economic Research. - http://www.ibser.org.ua/news.

13. Data about General Budget of Ukraine: The Budget Committee of Verkhovina Rada of Ukraine. http:/budget.rada.gov.ua/kombjudjet/control/uk.

14. Conclusions about General Budget in Ukraine: Verkhovna Budget Committee of Verkhowna Rada of Ukraine. - http:/www.acrada.gov.ua/control/main/uk/search/results.

15. Data about level of the shadow economy in Ukraine: Ministry of Economic Development and Trade of Ukraine. - http://www me gov.ua.

Ryabushka, L. B. The influence of the shadow economy on budget revenues [Text] / Ryabushka L.B, Bondarkova D.V. // Nauka i studia. - 2013. - №20. - C.61-70. 